\title{
The Role of Employee Work Happiness towards Innovative Work Behavior Among Lecturers in Indonesia
}

\author{
Azhar El Hami ${ }^{1}$ and Megawati Batubara ${ }^{2}$ \\ ${ }^{1}$ Faculty of Psychology, Universitas Padjadjaran, Indonesia \\ ${ }^{2}$ Faculty of Psychology, Universitas Padjadjaran, Indonesia
}

\begin{abstract}
Employee work happiness have a positive effect not only on the workers themselves but also for the organization (Fisher, 2010). Estrada, Isen, \& Young (1994) stated that happy workers can create a performance that can increase company productivity. In the era of global competition in the business world, innovative work behavior becomes a demand that can support the company success (Oukes, Veneendaal, \& Hoffman, 2011). Similarly, at the education field where the level of competition between colleges in Indonesia is increasingly strictly today. It require the innovative among the lecturer while they doing their job, the Tri Dharma Perguruan Tinggi (Education, Research \& Community Services). The purpose of this study is to find out the role of work happiness toward innovative work behavior among the lecturer in Indonesia. This research conducted to 107 lecturers at one of the universities in Indonesia. The respondents were asked to fill out 2 questionnaires, i.e. (1) Lecturer's Work Happiness Scale; and (2) Lecturer's Innovative Work Behavior Scale. Both of these measurements were designed by researchers based on Fisher's (2010) theory of Work Happiness and De Jong \& Den Hartogg (2008) with Innovative Work Behavior Theory in Lecturer Context. Based on reliability test show that the alpha cronbach value are around 0.90. The research data were analyzing using SPSS ver. 20 (Statistic Regression). The results show that the role of Work Happiness gave 37.7\% to the formation of Innovative Work Behavior among the Lecturers.
\end{abstract}

Keywords: Work Happiness, Innovative Work Behavior, Lecturer

\section{Introduction}

Happiness is the important thing for every people and even it becomes the ultimate goal of life (Diener, 2000). The topics of happiness become popular in these days on psychological research since the emerging of positive psychology in the last few decades (Seliman and Csikzentmihalyi, 2000). Diener (2000) categorizes the definition of happiness into three groups, the first in which happiness is defined as the attainment of a quality of life; second, happiness is the result of an evaluation of his life; and third, happiness is defined as a pleasant feeling condition in his life. Based on those definitions, happiness is pleasant feeling condition as result of individual evaluation on his life. Similarly at work context, that work happiness is a pleasant condition toward individual various situations while their doing their jobs.

Topics on happiness at work have overlap with various topics in research on organizations (Fisher 2010). At the individual level, the topics are related to job satisfaction, affective commitment, job-involvement, workengagement and mood conditions at work. While measuring the happiness at work, it is not separated on the three target of happiness (Fisher, 2010), i.e. (1) The Work It Self. This is related to the extent to which individual attachments to the work are cognitively and affectively and how they enjoy their work; (2) WorkContext. In this case it relates to the level of individual satisfaction through cognitive evaluation about their work context, including salary, boss, coworker and working conditions; and (3) The Organization as a whole, i.e. the extent to which the individual has a pleasant feeling towards the organization where their work. Theirs have an affective commitment to the organization, as feeling of attached, belong and value match between personal 
and the organizational. These three measures are expected can measure the variance of individual work happiness.

The impact of happiness at work is not only for the individual, but also for the organization (Fisher, 2010). This positive feeling can encourage individuals to think creatively and proactively and also predict the same behavior in another day (Amabile et al., 2005; Fritz and Sonnentag 2009). In addition, these positive feelings will have an impact on how individuals evaluate their environment at work, including an increase in job satisfaction scores (Brief et al. 1995; Kraiger et al., 1989). Estrada, Isen, \& Young (1994) stated that happy workers can create a performance that will improve company productivity. Harrison et al. (2006) also states that work attitude, that is job satisfaction and work commitment, has an impact on individual effectiveness at work. Based on the above, the happiness at work has a positive impact for the individual and the organization and can encourage the individual to think creatively in order to produce innovative work behavior.

In today's business competitive, innovative become necessary required (Johnson et al., 2008). Employee innovation is needed in terms of products, processes, methods and also in operational activities (Ramamoorthy et al., 2005). Innovative work behavior becomes necessary close to the workers daily activities for the organizational benefit (e.g. Scott \& Bruce, 1994, 1998; De Jong \& Den Hartog, 2010; Oukes, Veneendaal, \& Hoffman, 2011). De Jong (2007, p.8) defines Innovative Work Behavior (IWB) as an intended individual behavior to introduce and/or apply new ideas, products, processes and work procedures on its work. This Innovative Work Behavior concerns both initiating and implementing behavior during the innovation process phase. This individual innovation begins with exploring ideas that can be applied, such as looking for area of development for existing products, services and work processes. Then the new ideas are conceptualized towards products, services and work processes. Both processes (exploring ideas and conceptualized the new idea) are included in the initiation stage of the innovation process. The next step is championing, which is the effort to seek support, build collaboration, negotiate and influence various parties to support the new idea. After that, the ideas are implemented. At this stage, all ideas are developed, tried and modified (e.g. De Jong, 2007; Zaltman et al., 1973).

Similarly at higher education. Innovative behavior is important things to be part at education process, which is the level of competition that will be tightly by the year of 2025. Lecturers are one of the elements that are required to be innovated while doing their job. According to Indonesian Republic Law No. 14/2005, Lecturer is a professional educator and scientist with the main task of transforming, developing, and disseminating science, technology, and art through education, research, and community service (Tri Dharma Perguruan Tinggi). Therefore the innovative work behavior among lecturers in Indonesia is an important thing and is required to answer the future challenge.

Based on the exposure, work happiness becomes an important factor for the formation of productive behavior that gives positive impact to the organization. Productive behavior in the current era, not only meets the demands of work, but also required to be innovative in carrying out its duties. Not only the workers who work in a company, but also lecturers as the spearhead of higher education. The lecturer is required to be innovative in order to win the global competition today. But there some questions arise. How is the relationship between work happiness and innovative work behavior among lecturer? How much the role of work happiness to formation of innovative work behavior? There is less research had conducted about work happiness and its impact on innovative work behavior. In addition, the context of duties and functions of lecturers themselves have not been much studied either associated with work happiness and innovative work behavior.

\section{Research Methodolgy}

The purposes of this study are to find the role of work happiness toward innovative work behavior among lecturers in Indonesia. The participants of this research are the lecturers at one of universities in Indonesia. Participants were given two questionnaires. First, Lecturer's Work Happiness Scale (LWHS), designed by researchers based on Fisher's (2010) theory of Happiness at Work. This instrument consists of 3 measured 
aspects namely (1) Work It Self; (2) Work Context; (3) The Organization. The LWHS consists of 27 items (each aspect consists of 9 items) where the content of the item is designed to related to lecturers duties, The Tri Dharma Perguruan Tinggi (Education, Research and Community Service). After the try out, the reliability coefficient of LWHS is $\alpha=0.94$.

The second questionnaire is Lecturer's Innovative Work Behavior Scale (LIWBS) which also designed by researchers based on the theory of De jong \& De Hartogg (2008) about Innovative Work Behaviour. This measurement consists of four dimensions (1) Opportunity to Exploration; (2) Generating Idea; (3) Championing; and (4) Application. The number of items from this measuring instrument is 36 items (each dimension consists of 9 items) which also designed by relating it to the duty and function of the lecturer, the Tri Dharma Perguruan Tinggi (Education, Research and Community Service). The apha cronbach value of this LIWBS is $\alpha=0.97$. This means that the LIWBS is reliable to use. This research conducted 107 participants with the demographic data as shows at table 1 .

Tabel 1. Participants Demographic Data

\begin{tabular}{lllllr} 
Gender & Men & 41 & Employee & $\begin{array}{l}\text { Government Employee } \\
\text { University Employee }\end{array}$ & 72 \\
& Woman & 66 & Status & Others \\
Age & $<35$ yo & 34 & & & 4 \\
& $35-44$ yo & 48 & Working & $<11$ years & 51 \\
& $45-54$ yo & 17 & Experience & $11-20$ years & 39 \\
& $>54$ yo & 13 & & $21-30$ years & 11 \\
\multirow{5}{*}{ Education } & & & & $>30$ years & 6 \\
& Master & 75 & & &
\end{tabular}

Based on the table 1, the participants of this study were dominated by female $(61.7 \%)$ and the age range of participants was at 35 - 48 years (44.9\%). Most of the participants have Master degree (70.1\%) and the most employment status are civil servants $(67.3 \%)$. And the work experiences of the participants most are in the range under 11 years $(47.7 \%)$.

\section{Result \& Discussion}

After the data collected, the data was analysing by SPSS (regression test) to find the role of Work Happiness toward Innovative Work Behaviour among lecturers in Indonesia. The result found that the relationship between Work Happiness and Innovative Work Behaviour among the lecturers was $r=0.614(p=0.00<0.05)$. And the contribution of all the aspects of Work Happiness (Work It Self, Work Context and Organization) to emerging of Innovative Work Behaviour is $37.7 \%$. These results support previous research about the influences of work happiness toward innovative behaviour (Abdullah \& Ling, 2016; Abdullah at ell, 2016).

Meanwhile, to see other variables that affect the innovative work behaviour then used the formula as follows:

$$
\varepsilon=\sqrt{\rho} \rho-r^{2}
$$


Based on calculations, the research found that the amount effect from the other variables toward innovation work behaviour is $78.9 \%$. It means that there are some other factors can influence to emergence of innovation work behavior.

Table 2. Coefficient Value $\beta$ for influence of WH toward IWB

\begin{tabular}{|c|c|c|c|c|c|}
\hline \multicolumn{6}{|c|}{ Dependent Variable } \\
\hline & $\begin{array}{c}\text { Innovative } \\
\text { Work Behavior } \\
\text { (IWB) }\end{array}$ & $\begin{array}{l}\text { Opportuniy } \\
\text { Exploration } \\
\text { (OE) }\end{array}$ & $\begin{array}{c}\text { Idea } \\
\text { Generating } \\
\text { (IG) }\end{array}$ & $\begin{array}{c}\text { Championing } \\
\text { (Champ) }\end{array}$ & $\begin{array}{c}\text { Application } \\
\text { (App) }\end{array}$ \\
\hline & $\beta$ & $\beta$ & $\beta$ & $\beta$ & $\beta$ \\
\hline \multicolumn{6}{|l|}{ Independent Variable } \\
\hline 1. Work It Self (WiS) & $0.497 *$ & 0.03 & $0.534 *$ & $0.502 *$ & $0.389^{*}$ \\
\hline 2. Work Context (WC) & 0.000 & $0.453^{*}$ & -0.66 & -0.154 & -0.042 \\
\hline 3. Organization (Org) & 0.181 & $0.402 *$ & 0.172 & 0.178 & 0.128 \\
\hline $\mathrm{R}$ & $0.614^{*}$ & $0.793^{*}$ & $0.616^{*}$ & $0.562 *$ & $0.453^{*}$ \\
\hline $\mathrm{R}^{2}$ & 0.377 & 0.629 & 0.38 & 0.316 & 0.205 \\
\hline F Value & 20.806 & 58.164 & 21.042 & 15.847 & 8.859 \\
\hline
\end{tabular}

If we analyze to the aspects of Work Happiness (Table 2), it appears that the Work It Self has a significant role for the emergence of innovative work behaviors, especially in the process of generating ideas, championing and application. While Work Context and Organization have no significant contribution for the emergence of innovative work behavior. Both of these aspects have a role at the opportunity to exploration stage.

Fisher (2010) said that Work It Self is the extent to which the individual, in this case the lecturers, feels tied both cognitively and affectively as well as how he enjoys his work. This concept according to Fisher (2010) itself refers to the work-engagement by Bakker and Demerouti (2008). In this case, how lecturers enjoy his work both in teaching, doing a research and community service will encourage them to bring up such innovative work behavior. These results support previous studies of work engagement and innovative work behaviors (Rao, 2016, Spiegelaer, 2015; Kim \& Park, 2017; Lin \& Lee, 2017).

Meanwhile, based on the results of this study, it seems that the lecturers initiate an innovation, i.e. exploring to get the opportunity to develop a product, work process and service (OE), will depend on their satisfaction to their job context (i.e. the colleagues, work situation, salary, etc.) and feel belonging to organization. Indeed, these three aspects of Work Happiness together have a role about $79.3 \%$ for changes on innovative work behavior. But only two aspects (Work Context and Organization) have more influences for lecturers to do some explore to find possibilities area of development (OE) in their jobs (WC $\beta=0.453$ and $\operatorname{Org} \beta=402$, Sig. $\mathrm{P}$ $<0.05$ ). While the Work It Self aspect has no significant role to OE (WiS $\beta=0.03$, Sig. P $>0.05$ ).

In the next process, the whole aspect of Work Happiness together has a role to the emergence of each stage in the process of Innovative Work Behaviour among the lecturers, i.e. idea generating $\beta=0.616$; Championing $\beta$ $=0.562$; and Application $\beta=0.453$ (Sig $\mathrm{p}<0.05$ ). However, the Work It Self aspect have a larger influence than two other aspects (Work Context and Organization) in generating that behavior ( $\beta=0.534$ for IG; $\beta=0.52$ for Champ; $\beta=0.389$ for App. $\mathrm{P}<0.05$ ). This means that the more their feels engage with their work as lecturer the greater chances for bringing up the next stage of innovative work behaviour, that is how they conceptualize their own ideas, try to convince the various parties and apply the ideas on their work.

Interestingly from this research, the result of this study is the declining role of the whole aspect of the Work Happiness as together on every stage of Innovative Work Behaviour (EO - $\beta=0.793$; IG - $\beta=0.616$; Champ - $\beta$ $=0.562$; App $-\beta=0.453$ ). This shows that as the stage progresses in Innovative Work Behaviour, the greater of the other variables, outside the Work Happiness, contributes to the emergence of innovative work behaviour. 


\section{Conclusion}

The results of this study show that Work Happiness has an influence on the emergence of Innovative Work Behaviour in Lecturers in Indonesia. If we look at each of the stages of Innovative Work Behaviour, then the whole aspect of Work Happiness (i.e. Work It Self, Work Context and Organization) jointly influence the emergence of Opportunity Exploration, Idea Generating, Championing and Application. In the opportunity exploration stage, the Work Context and Organization aspects have a role in encouraging the behaviour of the lecturers to conduct explorations to get ideas in making improvements to the products, work processes and services provided. This means that a sense of satisfaction with working conditions and also a strong sense of belonging to the organization becomes the basis for the appearance of behaviour to conduct the exploration. While in the next stage it appears that the role of the lecturer enjoying his work (Work It Self) has a deeper role to generate the ideas (conceptualize an idea), convince others of the ideas and apply them to the job. Looking at each stage of Innovative Work Behaviour, it seems that the contribution of Work Happiness is declining as the stage of Innovative Work Behaviour, which means the greater role from the other factors, outside of Work Happiness, that can encourage Lecturers to elicit innovative work behaviour.

Subsequent research related to other factors that play a role in the emergence of innovative work behavior seems necessary. The role of personality and also the environment seems to need attention to be explored. In addition, it is also necessary to explore different organizations to see how far the role of work happiness influences innovative work behavior.

\section{References}

[1] Abdullah, Ghani K A., Ling, Ying-Leh, "The Mediating Role of Workplace Happiness on Teachers' Innovative Behavior and Affective Commitment for Malaysian Secondary Schools: A Cross-Sectional Questionnaire Survey", Teacher Education and Curriculum Studies, vol. 1, No. 1, 2016, pp. 15-19. doi: 10.11648/j.tecs.20160101.12

[2] Abdullah, Ghani K A., Ling, Ying-Leh., Ping, C.S., Yusoff, Zaiyah., "The Influnce of Workplace Happiness Toward Innovative Behavior and Affective Commitmen Among The Teachers in Northern Peninsular Malaysia”, RA Journal of Applied Research, Vol.2,Issue04, 2016, pp.445-450.

[3] Brief, A.P., Butcher, A.H. and Roberson, L., "Cookies, disposition, and job attitudes: the effects of positive moodinducing events and negative affectivity on job satisfaction in a field experiment", Organizational Behavior \& Human Decision Processes, 62, 1995, pp. 55- 62.

[4] Diener, E.. "Subjective well-being: The science of happiness and proposal for a national index," American Psychologist, vol. 55 (1), 2000; pp. 34-43.

[5] De Jong, J., "Individual innovation: The connection between leadership and employees' innovative work behavior," 2007. PhD University of Twente, EIM: Zoetermeer.

[6] De Jong, J.P.J. \& Den Hartog, D.N. (2010). , "Measuring innovative work behavior," Creativity and Innovation Management, 19(1), 2010. Pp. 23-26.

[7] E. P. Seligman, Martin \& Csikszentmihalyi, Mihaly, "Positive Psychology: An Introduction. The American psychologist”, vol. 55, pp. 5-14., 2000. DOI 10.1037/0003-066X.55.1.5.

[8] Estrada, C.A., Isen, A.M. \& Young, M.J. "Positive affect improves creative problem solving and influences reported source of practice satisfaction in physicians," Motivation \& Emotion, vol 18: 285, 1994. https://doi.org/10.1007/BF02856470

[9] Fisher, Cyntia D, “Happiness at Work,” International Journal of Management Review, vol.12, pp. 384-412, 2010.

[10] Fritz, C. and Sonnentag, S., "Antecedents of day-level proactive behavior: a look at job stressors and positive affect during the workday". Journal of Management, 35, 2009, .pp. 94-111.

[11] Harrison, D.A., Newman, D.A. and Roth, P.L. "How important are job attitudes? Meta-analytic comparisons of integrative behavioral outcomes and time sequences," Academy of Management Journal, 49, 2006, pp. 305-325. 
[12] Johnson, G., K. Sholes and R. Whittington, "Exploring corporate strategy," $8^{\text {th }}$ Edition., 2008. London: Prentice Hall

[13] Kim, Woocheol., and Park, Jiwon., "Examining Structural Relationship between Work Engagement, Organizational Procedural Justice, Knowledge Sharing, and Innovative Work Behavior for Sustainable Organizations," Sustainablitiy, vol.9, No. 205, 2017; pp. 1-16, doi:10.3390/su9020205

[14] Kraiger, K., Billings, R.S. and Isen, A.M., "The influence of positive affective states on task perceptions and satisfaction," Organizational Behavior \& Human Decision Processes, 44, 2989, pp. 12-25.

[15] Lin, Hsiu-Chuan \& Lee, Yuan-Duen., "A study of the influence of Organizational Learning on Employees Innovative Behavior and Work Engagement by a Cross-level Examination," Eurasia Journal of Mathematics, Science and Techology Education, vol.13, No.7, 2017; pp. 3463-3478. DOI 10.12973/eurasia.2017.00738a

[16] Rank, Johannes \& Frese, Michael. (Amabile et al. 2005; "The impact of emotions, moods and other affect-related variables on creativity, innovation and initiative," Publ. in: Research Companion to Emotion In Organizations / Neal M. Ashkanasy, Neal M. Ashkanasy (eds.). Cheltenham, UK: Edward Elgar Publ., 2008, pp. 103-119. . $10.4337 / 9781848443778.00015$.

[17] Ramamoorthy, N., Flood, P. C., Slattery, T., \& Sardessai, R., "Determinants of innovative work behaviour: development and test of an integrated model. Creativity \& Innovation Management," 14(2), 2005, pp. 142-150.

[18] Scott, S.G., \& R.A. Bruce, "Determinants of innovative behavior: A path model of individual innovation in the workplace," Academy of Management Journal, 38, 1994, pp. 1442-1465.

[19] Scott, S.G., \& R.A. Bruce, “Following the leader in R\&D: The joint effect of subordinate problem-solving style and leader-member relations on innovative behavior" IEEE Transactions on Engineering Management, 45 (1), 1998, pp. 3-10

[20] T. Oukes, "Innovative Work Behavior: A Case Study at Tire Manufacturing," Bachelor thesis, Business Administration, University of Twente, Netherland, 2010.

[21] Zaltman, G., Duncan, R. \& Holbek, J., “Innovations and organizations”. 1973. New York: John Wiley. 